\title{
Influence of Brine Concentration, Brine Temperature, and Presalting on Early Gas Defects in Raw Milk Pasta Filata Cheese*
}

\author{
C. Melilli, ${ }^{1}$ D. M. Barbano, ${ }^{2}$ M. Caccamo, ${ }^{1}$ M. A. Calvo, ${ }^{1}$ G. Schembari, ${ }^{1}$ and G. Licitra ${ }^{1,3}$ \\ ${ }^{1}$ CoRFiLaC, Regione Siciliana, 97100 Ragusa, Italy \\ ${ }^{2}$ Northeast Dairy Food Research Center, Department of Food Science, \\ Cornell University, Ithaca, NY 14853 \\ ${ }^{3}$ Dipartimento di Scienze Agronomiche, Agrochimiche e delle Produzioni Animali, \\ Catania University, Via Valdisavoia 5, 95100 Catania, Italy
}

\section{ABSTRACT}

Thirty-one 3.8-kg blocks of Ragusano cheese were made on each of $6 \mathrm{~d}$ starting with a different batch of raw milk on each day. On d 1,3 , and 5 , cheeses were not presalted and on $\mathrm{d} 2,4$, and 6 , all cheeses were presalted. Before brine salting, one of the 31 blocks of cheese was selected at random for analysis (i.e., at $d$ 0 ). The remaining 30 blocks were randomly divided into 2 batches of 15 blocks each, one group was placed in $18 \%$ brine, and the other group was placed in saturated brine. For the 15 blocks within each of the 2 brine concentrations, 5 blocks each were placed in brine tanks at 12,15 , and $18^{\circ} \mathrm{C}$. Cheese blocks were sampled immediately before brine salting (d 0) and after 1, 4, 8, 16, and $24 \mathrm{~d}$ of brine salting. Presalting the curd with $2 \%$ added salt before stretching reduced the coliform count in the cheese by $1.41 \mathrm{log}$ and resulted in a major reduction in early gas formation. Across all treatments in the present study, the average reduction in gas formation due to presalting was $75 \%$. Reducing brine temperature had the second largest impact on reducing gas production, but did not reduce the coliform count in the cheese. Reducing brine temperature from 18 to $12^{\circ} \mathrm{C}$ made a larger reduction in early gas formation in cheeses that were not presalted (from 6.8 to $1.8 \%$ gas holes, respectively) than in cheeses that were presalted (from 1.9 to $0.5 \%$ gas holes, respectively). To achieve the same absolute level of gas production in the nonpresalted cheese as was achieved in presalted cheese in combination with $18^{\circ} \mathrm{C}$ brine, the brine temperature for the nonpresalted cheese had to be lowered from 18 to $12^{\circ} \mathrm{C}$. Reducing brine concentration, although effective

Received November 4, 2003.

Accepted May 15, 2004.

Corresponding author: D. M. Barbano; e-mail: dmb37@cornell.edu.

*Use of names, names of ingredients, and identification of specific models of equipment is for scientific clarity and does not constitute any endorsement of product by authors, Cornell University, the Northeast Dairy Foods Research Center, CoRFiLaC, or Dipartimento di Scienze Agronomiche, Agrochimiche e delle Produzioni Animali, Catania University. at increasing the rate of salt penetration into the block, did not have any impact on coliform count and had minimal impact on reducing gas production. The condition where reducing brine concentration was able to make a reduction in gas production was for cheeses that were not presalted and brined at $18^{\circ} \mathrm{C}$. Presalting is a very simple and practical approach to reducing the problem of early gas formation in combination with strategies to improve milk quality and cheese making conditions. Further work is needed to understand the impact of different levels of presalting on death of coliforms and gas production in the cheese.

(Key words: early gas, coliform, presalting, brine temperature)

Abbreviation key: BT = brine temperature, $\mathbf{B C}=$ brine concentration, nonPS $=$ nonpresalted, $\mathbf{P S}=$ presalted, $\mathbf{S B}=$ saturated brine, $\mathbf{1 8 \%} \mathbf{B}=18 \%$ brine.

\section{INTRODUCTION}

Ragusano cheese is a brine-salted, pasta-filata cheese, aged for 6 to $9 \mathrm{mo}$, which is still produced on farms in the Eastern region of Sicily. The cheese is made from raw milk, and lactic acid is produced by natural milk microflora and by desirable microflora present at the surface of the wooden cheese vat. Early gas formation in brine-salted cheeses made from raw milk is typically the result of poor milk quality, poor hygienic conditions during cheese making, slow acid production during cheese making, and slow uptake of salt from brine. The level of undesirable gas-forming bacteria present in cheese is dependent on their initial level in the milk; their growth is favored by slow acid production during cheese making (Choisy et al., 1987) and slow salt penetration during brining. Early gas formation in cheese is usually produced by coliform bacteria (Chapman and Sharpe, 1990). Ragusano cheese is brine-salted for up to $8 \mathrm{~d}$ at the farm, followed by continued brine salting at an aging center in saturated brine at $18^{\circ} \mathrm{C}$. When salt uptake by cheese during brining is too slow, early gas formation, in the form of 
small numerous holes and off-flavor development (Kosikowski and Mistry, 1997), occurs due to the growth of undesirable bacteria. Enterobacter aerogenes is a particularly strong producer of the early gas defect in cheeses and can be found in raw milk (Bester, 1976).

Resmini et al. (1974) found that salt uptake was faster when nonsaturated brine (approximately 16\%) was used for the first 5 to $6 \mathrm{~d}$ of brining followed by saturated brine (SB) until $24 \mathrm{~d}$. A study of Ragusano cheese by Melilli et al. (2003b) demonstrated that use of $18 \%$ brine $(\mathbf{1 8 \%} \mathrm{B})$ for the first $8 \mathrm{~d}$ of $24 \mathrm{~d}$ of brinesalting increased the rate of salt uptake, compared with $24 \mathrm{~d}$ in SB (26\%), in agreement with the results of Resmini et al. (1974). The cheese in $18 \% \mathrm{~B}$ at $18^{\circ} \mathrm{C}$ for $12 \mathrm{~d}$ achieved the same salt content as cheese in SB at $18^{\circ} \mathrm{C}$ for $24 \mathrm{~d}$. The increased rate of salt uptake with $18 \% \mathrm{~B}$ compared with SB was related to the impact of lower brine concentration on the moisture content and porosity of the cheese near the surface of the block. In the same study, cheeses that were presalted by addition of $2 \%$ salt by weight to the curd before stretching contained $60 \%$ of the final salt content in the center of the block as was achieved in $24 \mathrm{~d}$ of saturated salt brining without presalting. The presalting did not change the rate of salt uptake from $18 \% \mathrm{~B}$ or SB.

At the farm level, ambient brine temperature can vary seasonally from 10 to $24^{\circ} \mathrm{C}$ and this can influence the salt uptake. Geurts et al. (1974) showed that, for Gouda cheese, salt diffusion at $20^{\circ} \mathrm{C}$ was higher by 40 to $50 \%$ than at $12.5^{\circ} \mathrm{C}$. Turhan and Kaletunç (1992) found that for white cheese, a semi-hard pickled cheese (Carić, 1993), the salt penetration was slower with decreasing brine temperature because of decreased salt diffusivity. Melilli et al. (2003a) determined that salt uptake in Ragusano cheese increased when brine temperature was increased from 12 to $24^{\circ} \mathrm{C}$, but at brine temperatures higher than $18^{\circ} \mathrm{C}$, a stimulation of early gas production was noted, even though the salt uptake was faster. In the previous studies, no quantitative measurements of gas production were done. The objective of this research was to determine the combined impact of presalting the curd before stretching, brine concentration (BC) (saturated vs. 18\% salt brine), and brine temperature (BT) $\left(12,15\right.$, and $\left.18^{\circ} \mathrm{C}\right)$ on coliform count and development of early gas defects in Ragusano cheese.

\section{MATERIALS AND METHODS}

\section{Experimental Design and Statistical Analysis}

Thirty-one 3.8-kg blocks of Ragusano cheese were made on each of $6 \mathrm{~d}$ starting with a different batch of milk on each day. On d 1,3 , and 5 , the cheeses were not presalted (nonPS), and on d 2, 4, and 6, all cheeses were presalted (PS). Before brine salting, one of the 31 blocks of cheese was selected at random for analysis (i.e., at d 0). The remaining 30 blocks were randomly divided into 2 batches of 15 blocks each, one group was placed in $18 \% \mathrm{~B}$, and the other group was placed in SB. For the 15 blocks within each of the 2 brine concentrations, 5 blocks each were placed in brine tanks at 12 , 15 , and $18^{\circ} \mathrm{C}$. The ratio of the brine to cheese volume was kept at 5 or greater (Zorrilla and Rubiolo, 1991) so that salt uptake would not be limited. The blocks were kept submerged for $24 \mathrm{~d}$. The blocks of cheese were turned in the brine daily and the salinity of the brine was checked 4 times/d and adjusted when needed. Cheese blocks were sampled immediately before brine salting (d 0$)$ and after $1,4,8,16$, and $24 \mathrm{~d}$ of brine salting.

Data were analyzed using the GLM procedure of SAS (version 8, 1999, SAS Institute, Inc., Cary, NC). Data for salt-in-moisture in the cheese and coliform count $\left(\log _{10}\right)$ were analyzed using ANOVA model with terms for $\mathrm{BC}(\mathrm{SB}$ and $18 \% \mathrm{~B})$, BT $\left(12,15\right.$, and $\left.18^{\circ} \mathrm{C}\right)$, salting method (PS and nonPS), and day of brining (16 and 24). Means were tested for each term in the model using a $t$-test (LSD, $P<0.05$ ). The data for gas production in the cheese during brining (i.e., image analysis data) were analyzed using the split-plot ANOVA model. Image analysis data for gas production was collected at 0 , $1,4,8,16$, and $24 \mathrm{~d}$ of brining. Because time of brining was treated as a continuous variable in the ANOVA model, the linear and quadratic terms for time would be correlated. Distortion of the ANOVA by multicolinearity of these terms in the model was minimized by centering the time of brining data using a mathematical transformation (Glantz and Slinker, 2001). The time was transformed as follows: time $=\mathrm{d}$ of brining - [(last testing day - first testing day)/2]. This transformation made the data set orthogonal with respect to time.

\section{Cheese Making}

Six cheese makings were done during the period from February to March 2003. Milk produced by Brown Swiss, Holstein, and mixed breed cows from 3 farms, and from the 2 milkings (morning and evening) was commingled and transported to the CoRFiLaC pilot plant. The raw whole milk $(1300 \mathrm{~L})$ was heated in a plate and frame preheater to $35^{\circ} \mathrm{C}$ and pumped directly into 7 traditional wooden cheese vats. Ragusano cheese was manufactured using the procedures described by Melilli et al. (2003a,b). The milled curd was weighed and divided into 31 batches of curd ( $4 \mathrm{~kg}$ each). Three cheese makers stretched 31 batches of curd to produce 31 blocks of cheese $(15.2 \times 15.2 \times 15.2 \mathrm{~cm})$ that each weighed approximately $3.8 \mathrm{~kg}$ after stretching. For $3 \mathrm{~d}$ 
of cheese making, the cheese makers stretched 31 nonPS cheeses and for the other $3 \mathrm{~d}$, the cheese makers stretched 31 PS cheeses, following the procedures of Melilli et al. (2003a,b). On cheese making d 2, 4 and 6, the curd was presalted at a rate of $2 \%$ added salt and each block was stretched in $10 \mathrm{~L}$ of hot brine $(4.5 \%$ salt, $\mathrm{wt} / \mathrm{vol}$ ) to minimize salt loss during stretching (Melilli et al., 2003b). The temperature and $\mathrm{pH}$ of the curd during stretching was $48^{\circ} \mathrm{C}$ and 5.30 , respectively.

Each 3.8-kg block of cheese was marked with a letter (treatment) and a number (sampling day) so that the cheese could be correctly identified in the brine tank. After forming the blocks, one of the 31 blocks was sampled and analyzed before brining. The initial SB, used in this experiment, was one that had been used for many years in a commercial Ragusano cheese aging center. Old SB was used because it contained a normal calcium content and $\mathrm{pH}$, which would avoid the defect of cheese rind softening, the loss of the deep yellow color, and stickiness (Geurts et al., 1972) that can occur with a new brine that contains no calcium and has high $\mathrm{pH}$. The $18 \% \mathrm{~B}$ solution was prepared from some of the old SB by diluting with water to reach a concentration of $18 \%$ salt (wt/vol). The $\mathrm{pH}$ of the $18 \%$ brine was adjusted by adding lactic acid to achieve the same $\mathrm{pH}$ as the saturated brine ( $\mathrm{pH}=5.20$, approximately). The brines were prepared $15 \mathrm{~d}$ before the experiment and placed in tanks in controlled temperature rooms to equilibrate before starting the experiment.

\section{Microbiological Sampling}

Each block was sampled to collect cheese from the P1, P2, P3, and P4 positions, as described previously (Melilli et al., 2003a,b), using a meat slicer (model 601003 , Electrolux, Zanussi Italia s.p.a, Pordenone, Italy). Each experimental block $(15.2 \times 15.2 \times 15.2 \mathrm{~cm})$ of Ragusano cheese, on the sampling day, was weighed and divided into 4 portions: P1, P2, P3, and P4, as follows. The exterior portion (P1) represented all 6 faces of the block (approximately 0.6-cm thick). Following removal of $\mathrm{P} 1$, the $\mathrm{P} 2$ portion was removed (approximately 1-cm thick) from all 6 faces of the block. The P3 portion (approximately $1-\mathrm{cm}$ thick) was removed next, leaving a cube of about $10 \times 10 \times 10 \mathrm{~cm}$ as the central portion (P4) of the cheese block. A core sample was removed aseptically from the $\mathrm{P} 4$ portion of the block for coliform analysis.

\section{Chemical and Microbiological Analyses}

A milk sample was collected, randomly, from 1 of 7 cheese vats at $35^{\circ} \mathrm{C}$, and tested for fat, $\mathrm{CP}$, and lactose content using an infrared milk analyzer (AOAC, 2000; method number 33.2.31; 972.16), for somatic cell count using a Fossomatic cell counter (AOAC, 2000; method number 17.13 .01 ; 978.26), for titratable acidity measured as degrees Soxhlet-Henkel ( $\left.{ }^{\circ} \mathrm{SH}\right)$ and converted to percentage lactic acid $\left(\left[{ }^{\circ} \mathrm{SH}=\mathrm{mL} \mathrm{NaOH} \times 100 \times \mathrm{N}\right] /\right.$ $[\mathrm{V} \times 0.25]$, where $\mathrm{N}=$ normality and $\mathrm{V}=$ volume, and \% lactic acid $=0.0225 \times{ }^{\circ} \mathrm{SH}$ ), and $\mathrm{pH}$ (gel-filled electrode model: HA405-DXK-S8/120, Mettler Toledo Process Analytical, Inc., Wilmington, MA). Sterile samples were also collected to determine the total bacteria (Marshall, 1992; method 6.2), and coliform counts (Marshall, 1992; method 7.13). The average raw whole milk used in 6 cheese-making sessions had a titratable acidity of 0.13 $\mathrm{g}$ of lactic acid/100 mL, and a $\mathrm{pH}$ of 6.70 at $35^{\circ} \mathrm{C}$. The fat, CP, and lactose contents were $3.26,3.27$, and $4.70 \%$, respectively, with an average somatic cell count of 400,000 cells $/ \mathrm{mL}$. The total bacteria and coliform counts of the milk used to make the PS cheeses were 5.36 and $3.16 \log _{10} \mathrm{cfu}$, respectively, and the total bacteria and coliform counts of the milk used to make the nonPS cheeses were 5.01 and $3.00 \log _{10}$ cfu, respectively.

Moisture content of cheese was determined by drying a 3-g sample in a forced air oven at $100^{\circ} \mathrm{C}$ for $24 \mathrm{~h}$ (AOAC, 2000, method number 33.2.44; 990.20); salt content was determined by the Volhard method (AOAC, 2000, method number 33.7.1; 935.43). A gel-filled electrode (model: HA405-DXK-S8/120, Mettler Toledo Process Analytical, Inc.) was used to determine cheese $\mathrm{pH}$.

Eleven grams of cheese and $99 \mathrm{~mL}$ of dilution water were placed into a Stomacher bag, the outside surface of the bag was kneaded by hand to disperse the cheese, and then the contents were blended with a Stomacher (model 400, BA 7021, Seward, Milan, Italy) for 3 to 6 min, depending on the age of the cheese. Older cheese was harder to disperse and was blended for as long as $6 \mathrm{~min}$. The cheeses were tested for coliform count using Petrifilm Coliform count plates (Marshall, 1992, method 7.13), after 16 and $24 \mathrm{~d}$ of brining.

\section{Image Analysis for Gas Production in Cheese}

Cheeses were sampled at d 0 (before brining), 1, 4, 8,16 , and $24 \mathrm{~d}$. After the sample for microbiological analysis was removed from the $\mathrm{P} 4$ portion, as described earlier, the remaining segment of the $\mathrm{P} 4$ portion was cut into $51-\mathrm{cm}$ thick slices with a meat slicer, starting sequentially from one face. The second and fifth slices were used to measure the gas holes and mechanical openness by image analysis (Caccamo et al., 2004). Pictures were taken of each side of each slice, and the 4 images were analyzed using MATLAB (Version 6.0.0.88, 2000, The Mathworks, Inc., Asheboro, NC).

The method of Caccamo et al. (2004) was used to measure the surface area of cheese slices occupied by 
Table 1. Mean values (\%) of the salt-in-moisture for the P4 portion of the cheese for presalted and nonpresalted cheeses at 2 brine concentrations and 3 brining temperatures at d 0,16 , and 24 of brining.

\begin{tabular}{llll}
\hline & \multicolumn{3}{c}{ Salt-in-moisture (\%) } \\
\cline { 2 - 4 } Variable & $\mathrm{d} 0$ & $\mathrm{~d} 16$ & $\mathrm{~d} 24$ \\
\hline Salting method & & & \\
Presalting & $2.16^{\mathrm{a}}$ & $4.83^{\mathrm{a}}$ & $7.36^{\mathrm{a}}$ \\
No presalting & $0.25^{\mathrm{b}}$ & $2.98^{\mathrm{b}}$ & $4.51^{\mathrm{b}}$ \\
LSD & 0.21 & 0.32 & 0.70 \\
Brine concentration & & & \\
Saturated brine & $1.20^{\mathrm{a}}$ & $3.54^{\mathrm{b}}$ & $5.56^{\mathrm{b}}$ \\
$18 \%$ brine & $1.20^{\mathrm{a}}$ & $4.27^{\mathrm{a}}$ & $6.31^{\mathrm{a}}$ \\
LSD & 0.21 & 0.32 & 0.70 \\
Brine temperature & & & \\
$12^{\circ} \mathrm{C}$ & $1.20^{\mathrm{a}}$ & $3.44^{\mathrm{c}}$ & $5.22^{\mathrm{b}}$ \\
$15^{\circ} \mathrm{C}$ & $1.20^{\mathrm{a}}$ & $3.92^{\mathrm{b}}$ & $5.98^{\mathrm{ab}}$ \\
$18^{\circ} \mathrm{C}$ & $1.20^{\mathrm{a}}$ & $4.35^{\mathrm{a}}$ & $6.60^{\mathrm{a}}$ \\
$\mathrm{LSD}$ & 0.26 & 0.40 & 0.85 \\
\hline
\end{tabular}

a,b,c Means within salting method, brine concentration, and brine temperature not sharing the same superscript are different $(P<0.05)$.

gas holes. A digital camera mounted on a copy stand with lighting was used to make digital images of each slice of cheese. A commercial digital image analysis software program was used and an algorithm written to measure the area of the image of the cheese slice occupied by holes. The image was cropped and scanned to determine which color channel produced the best image contrast. The MATLAB program allowed the analyst to identify and eliminate holes due to mechanical openness and then scan the image to produce a percentage distribution of pixels in the image as a function of pixel intensity. The program asked the analyst if there were any mechanical openings (i.e., false gas holes) in the image. If yes, the analyst selected the mechanical opening(s) on the image and the program rescanned the image not considering the mechanical openings as gas holes. The analyst then determined a threshold value to differentiate pixels that were in holes from those representing areas with no holes. The percentage of the total surface area occupied by gas holes was calculated.

\section{RESULTS}

Cheesemaking. Presalting the milled curd with $2 \%$ added salt before stretching, and then stretching in water containing $4.5 \%$ salt made the curd firmer; the force required to stretch the cheese increased compared with cheese curd with no added salt. If the curd was being stretched by machine, this change in viscoelastic properties would hardly be noticeable, but a person hand stretching the cheese would notice the difference. Based on experience with a no-brine Mozzarella cheese making process (Barbano et al., 1994), the firmness and work required for stretching increases with an increas-
Table 2. Mean values of the $\log _{10}$ of coliform count for presalted and nonpresalted cheeses at 2 brine concentrations, 3 brining temperatures, and 2 brining times.

\begin{tabular}{ll}
\hline Variable & $\begin{array}{l}\text { Coliform count } \\
\left(\log _{10} \mathrm{cfu}\right)\end{array}$ \\
\hline $\begin{array}{l}\text { Salting method } \\
\text { Presalting }\end{array}$ & $4.33^{\mathrm{b}}$ \\
No presalting & $5.74^{\mathrm{a}}$ \\
Brine concentration & \\
Saturated brine & $5.18^{\mathrm{a}}$ \\
$18 \%$ brine & $4.90^{\mathrm{a}}$ \\
Time of brining & \\
$\mathrm{d} 16$ & $5.04^{\mathrm{a}}$ \\
$\mathrm{d} 24$ & $5.03^{\mathrm{a}}$ \\
Brining temperature & \\
$12^{\circ} \mathrm{C}$ & $5.04^{\mathrm{a}}$ \\
$15^{\circ} \mathrm{C}$ & $4.79^{\mathrm{a}}$ \\
$18^{\circ} \mathrm{C}$ & $5.28^{\mathrm{a}}$ \\
\hline a,b Means within salting method, brine concentration, time of brin- \\
ing, and brine temperature not sharing the same superscript are \\
different $(P<0.05)$.
\end{tabular}

ing amount of added salt; however, it is not clear if the increase is a linear function of salt concentration. A systems analysis approach (Mulvaney et al., 1997) is needed to characterize the change in viscoelastic properties of the cheese with different levels of salt addition before stretching.

Salt-in-moisture of the cheese. The gas production measurements by image analysis and microbial counts were done on the P4 portion (center) of the blocks of cheese. The salt-in-moisture contents of the $\mathrm{P} 4$ portions of the cheeses are shown in Table 1 . There were significant $(P<0.05)$ impacts of PS, BC, and BT on the saltin-moisture content of the $\mathrm{P} 4$ portion of the cheese. As expected at $\mathrm{d} 0$ before brining, only PS had an effect on salt-in-moisture (Table 1). Both PS and nonPS cheeses increased in salt-in-moisture, but between d 16 and 24, the PS cheese took up more salt from brine than nonPS cheese. This may indicate that presalting has an impact on the formation of a barrier layer at the surface of the block (which retards salt penetration, Melilli et al. $2003 b$ ) when the cheese is placed in brine. Cheeses in 18\%B took up salt faster $(P<0.05$ at $d 16$ and 24$)$ than cheese in SB, and the absolute difference in salt-inmoisture due to $\mathrm{BC}$ was about the same at 16 and 24 $\mathrm{d}$ of brining (Table 1). The difference due to $\mathrm{BC}$ was much lower than the difference in salt-in-moisture between PS and nonPS cheeses. This is consistent with the previous results of Melilli et al. (2003b). There was a significant $(P<0.05)$ impact of $\mathrm{BT}$, with decreasing $\mathrm{BT}$ resulting in lower salt-in-moisture (Table 1). This is consistent with the results of Melilli et al. (2003b). Decreasing the brine temperature by $3^{\circ} \mathrm{C}$ decreased salt-in-moisture by slightly less than increasing brine concentration from $18 \%$ to SB (Table 1). 


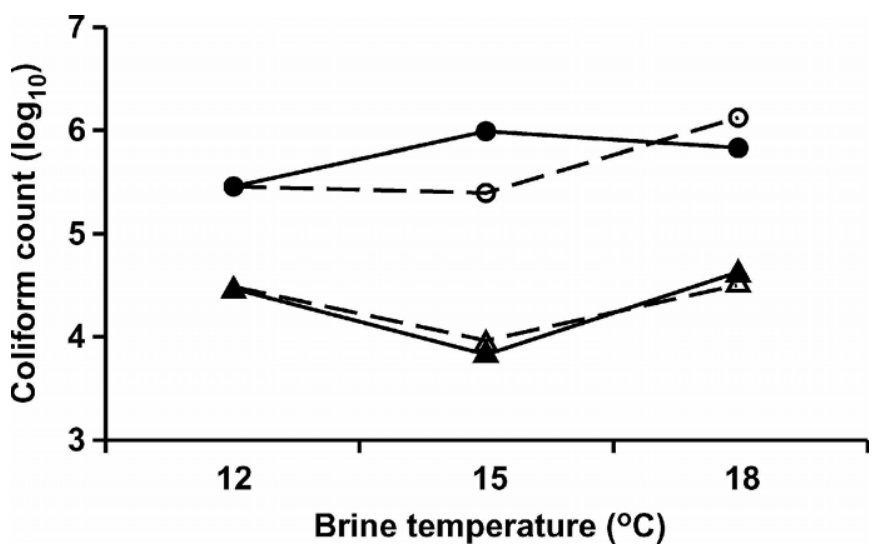

Figure 1. Impact of presalting vs. no presalting the curd on the coliform count (cfu) in cheeses kept in brines at 3 different temperatures $\left(12,15\right.$, and $\left.18^{\circ} \mathrm{C}\right)$ during 2 different days: $16 \mathrm{~d}$ for presalted $(\Delta)$ and nonpresalted cheese $(\bullet)$, and $24 \mathrm{~d}$ for presalted $(\triangle)$ and nonpresalted cheese $(O)$.

Coliform counts in cheese. The primary source of coliform in the cheeses in this study was the raw milk. There was an effect of presalting $(P<0.01)$ on coliform count in the cheese, but no effects were detected $(P>$ 0.05) of BC, BT, or days of brining on the coliform count of the cheese (Table 2). Presalting the curd before stretching reduced the coliform count by $1.4 \mathrm{log}$ (Table 2 ) and this effect was independent of BT and days of brining (Table 2 and Figure 1).

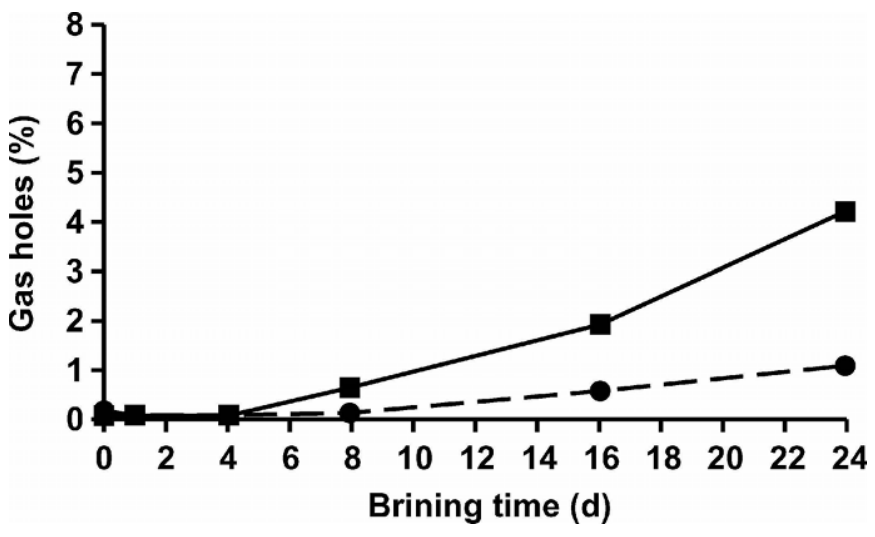

Figure 2. Impact of presalting: presalted (-) vs. not presalted (ם), on the percentage of gas holes at $0,1,4,8,16$, and $24 \mathrm{~d}$ of brining.

Gas production in cheese. Overall, presalting produced the largest decrease in gas production, followed by decreasing BT, and then decreasing BC. At $\mathrm{d} 0$, the PS cheeses contained approximately $2.16 \%$ salt-inmoisture before brining. There was a significant impact of BT $(P=0.03)$, and presalting $(P<0.01)$, but not BC on gas production during $24 \mathrm{~d}$ of brining (Table 3 ), with gas production decreased due to presalting (Figure 2) and decreasing BT (Figure 3), with presalting having a larger impact. There were significant 2 -way interactions of BT by presalting (Table 3 and Figure $4, P=$ 0.01 ) and BT by BC (Table 3 and Figure $5, P=0.03$ ).

Table 3. Sums of the squares (Type III SS) and probability values for the ANOVA analysis of the impact of salting method, brine concentration, and brine temperature on percentage of gas holes in cheese sampled at $0,1,4,8,16$, and $24 \mathrm{~d}$ of brining.

\begin{tabular}{lcccll}
\hline Factors $^{1}$ & df & Type III SS & $P$-value & Analyzed as & Error term \\
\hline Whole plot & & & & & \\
BC & 1 & 0.03 & 0.78 & Category & BC $\times$ BT $\times$ PS \\
BT & 2 & $8.09^{*}$ & 0.03 & Category & BC $\times$ BT $\times$ PS \\
PS & 1 & $10.29^{*}$ & $<0.01$ & Category & BC $\times$ BT $\times$ PS \\
BT $\times$ BC & 2 & $8.34^{*}$ & 0.03 & Interaction & BC $\times$ BT $\times$ PS \\
BT $\times$ PS & 2 & $14.53^{*}$ & 0.01 & Interaction & BC $\times$ BT $\times$ PS \\
BC $\times$ BT $\times$ PS & 3 & 0.81 & 0.65 & Interaction & Model error \\
Subplot & & & & & \\
$\mathrm{t}$ & 1 & $174.81^{*}$ & $<0.01$ & Continuous linear & Model error \\
$\mathrm{t} \times \mathrm{BC}$ & 1 & $3.94^{*}$ & $<0.01$ & Interaction & Model error \\
$\mathrm{t} \times \mathrm{BT}$ & 2 & $50.1^{*}$ & $<0.01$ & Interaction & Model error \\
$\mathrm{t} \times \mathrm{PS}$ & 1 & $69.56^{*}$ & $<0.01$ & Interaction & Model error \\
$\mathrm{t} \times \mathrm{BT} \times \mathrm{PS}$ & 2 & $13.36^{*}$ & $<0.01$ & Interaction & Model error \\
$\mathrm{t} \times \mathrm{BT} \times \mathrm{BC}$ & 2 & $8.84^{*}$ & $<0.01$ & Interaction \\
$\mathrm{t} \times \mathrm{t}$ & 1 & $13.92^{*}$ & $<0.01$ & Continuous quadratic & Model error \\
$\mathrm{t} \times \mathrm{t} \times \mathrm{BC}$ & 1 & $1.87^{*}$ & 0.05 & Interaction & Model error \\
$\mathrm{t} \times \mathrm{t} \times \mathrm{BT}$ & 2 & $3.45^{*}$ & 0.03 & Interaction & Model error \\
$\mathrm{t} \times \mathrm{t} \times \mathrm{PS}$ & 1 & $4.14^{*}$ & $<0.01$ & Interaction & Model error \\
Error & 190 & 93.42 & & & \\
$\mathrm{R}^{2}$ & & 0.81 & & & \\
\hline
\end{tabular}

*Statistically significant $(P<0.05)$.

${ }^{1} \mathrm{BC}=$ Brine concentration (saturated vs. $\left.18 \%\right) ; \mathrm{BT}=$ brine temperature $\left(12,15\right.$, and $\left.18^{\circ} \mathrm{C}\right) ; \mathrm{PS}=$ presalting (presalted vs. nonpresalted); $\mathrm{t}=$ time of brining. 


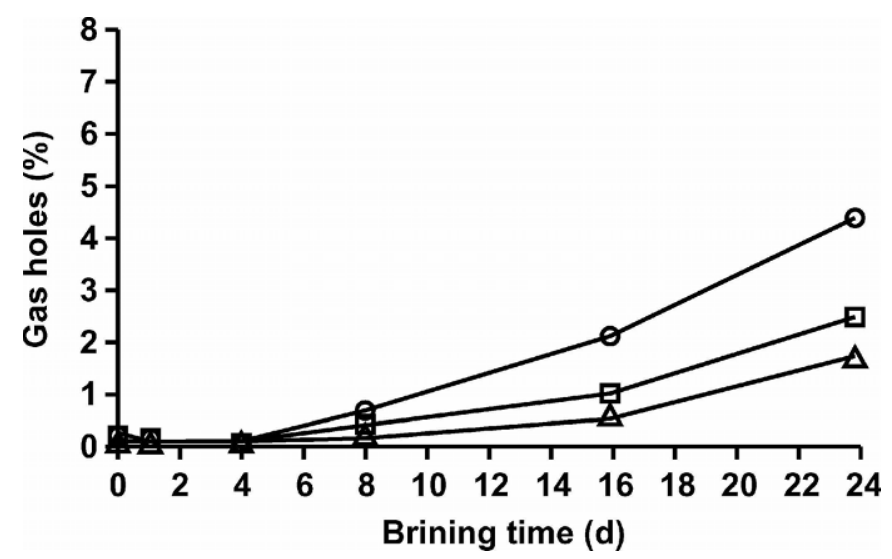

Figure 3. Figure 3. Impact of the interaction time by brine temperature: $12^{\circ} \mathrm{C}(\triangle), 15^{\circ} \mathrm{C}(\square)$, and $18^{\circ} \mathrm{C}(\bigcirc)$ on percentage of gas production in cheese at $0,1,4,8,16$, and $24 \mathrm{~d}$ of brining.

Increasing BT did not have much influence on gas production of PS cheeses. However, increasing BT made large increases in gas production in nonPS cheeses (Figure 4). Brine concentration did not have any influence on gas production for cheeses in 12 and $15^{\circ} \mathrm{C}$ brine, but gas production was higher in cheeses in $\mathrm{SB}$ at $18^{\circ} \mathrm{C}$ than in $18 \% \mathrm{~B}$ at $18^{\circ} \mathrm{C}$ because of the slower rate of salt penetration (Figure 5). The significant $(P=0.03) \mathrm{BC} \times$ $\mathrm{BT}$ interaction demonstrated (Table 3 ) that, at 12 and $15^{\circ} \mathrm{C}$, using $18 \% \mathrm{~B}$ instead of $\mathrm{SB}$ did not reduce gas production; however, at $18^{\circ} \mathrm{C}$, using $18 \% \mathrm{~B}$ instead of SB did decrease gas production.

There were significant increases in gas production with time of brining that had linear and quadratic components, and all the interactions of the main factors with the linear and quadratic component of time were significant (Table 3). The 2-way interaction of the linear

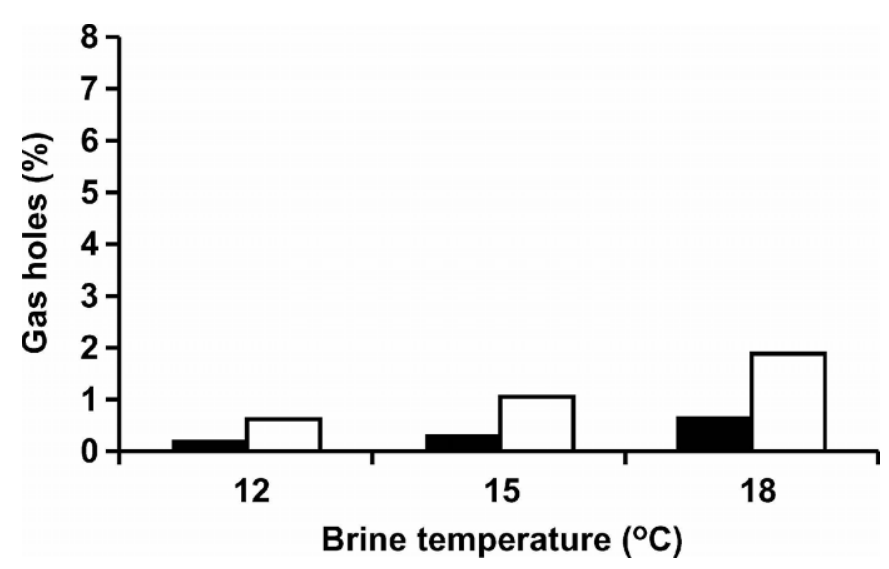

Figure 4. Impact of the interaction of brine temperature $(12,15$, and $18^{\circ} \mathrm{C}$ ) and salt, presalted (black bar) vs. nonpresalted (white bar), on the percentage of gas holes averaged across $24 \mathrm{~d}$ of brining.

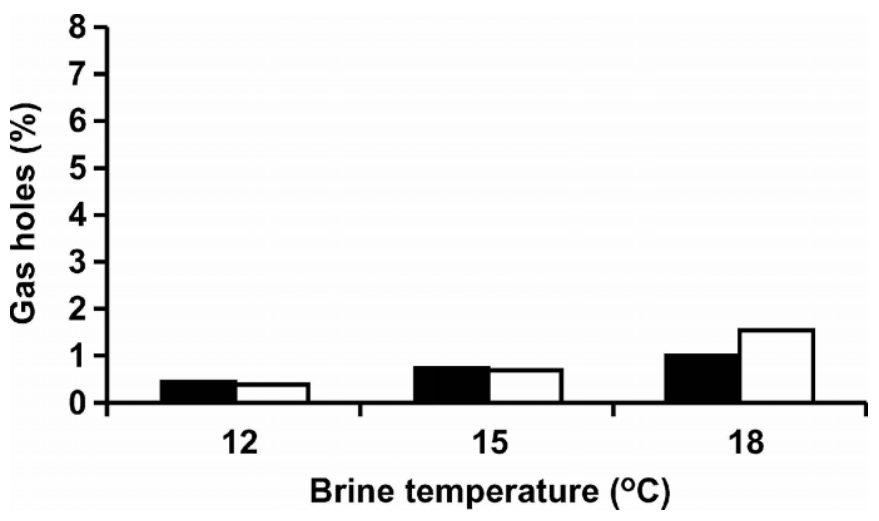

Figure 5. Impact of the interaction brine temperature $(12,15$, and $18^{\circ} \mathrm{C}$ ) and brine concentration, $18 \%$ brine (black bar) vs. saturated brine (white bar), on the percentage of gas holes averaged across 24 $\mathrm{d}$ of brining.

and quadratic component of time of brining $\times$ presalting had a significant effect $(P<0.01)$ on gas formation (Table 3), with PS cheeses developing much less gas than nonPS cheeses (Figure 2). The difference in gas production between PS and nonPS cheeses increased with time of brining (Figure 2). The increase in gas production for PS cheeses with time was linear and small, whereas the increase in gas production for nonPS cheeses was increasing at an increasing rate.

The interaction of the linear and quadratic components of time $\times$ BT (Table 3$)$ were significant $(P<0.01$ and $P=0.03$, respectively), with gas production increasing with increasing BT and time, as shown in Figure 3 . The 3 -way interaction effect of the linear term for time $(0,1,4,8,16$, and $24 \mathrm{~d}$ ), BC (saturated vs. 18\%),

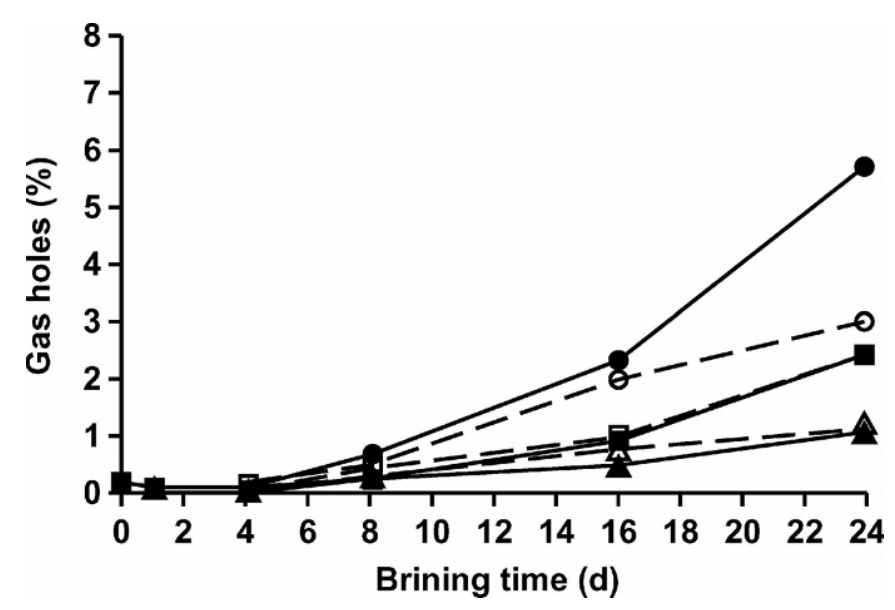

Figure 6. Effect of time of brining $(0,1,4,8,16$, and 24 d), brine concentration, and brine temperature on the percentage of gas holes in cheese. Treatments are: saturated brine at $12^{\circ} \mathrm{C}(\boldsymbol{\Delta})$, saturated brine at $15^{\circ} \mathrm{C}(\square)$, saturated brine at $18^{\circ} \mathrm{C}(\bullet), 18 \% \mathrm{~B}$ at $12^{\circ} \mathrm{C}(\triangle)$, $18 \% \mathrm{~B}$ at $15^{\circ} \mathrm{C}(\square)$, and $18 \% \mathrm{~B}$ at $18^{\circ} \mathrm{C}(\bigcirc)$. 


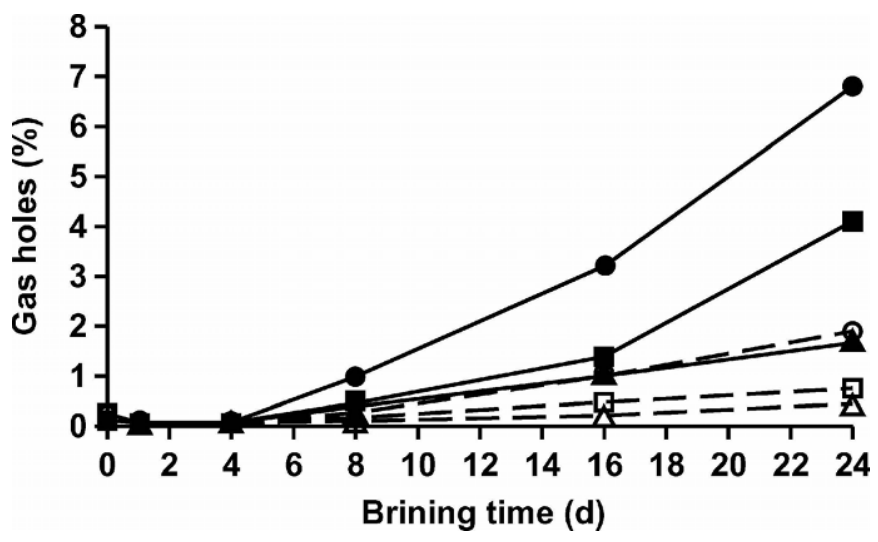

Figure 7. Effect of time of brining $(0,1,4,8,16$, and $24 \mathrm{~d})$, salt, and brine temperature on the percentage of gas holes in cheese. Treatments are: presalted, brine temperature at $12^{\circ} \mathrm{C}(\triangle)$, presalted, brine temperature at $15^{\circ} \mathrm{C}(\square)$, presalted, brine temperature at $18^{\circ} \mathrm{C}$ $(\bigcirc)$, not presalted, brine temperature at $12^{\circ} \mathrm{C}(\boldsymbol{\Delta})$, not presalted, brine temperature at $15^{\circ} \mathrm{C}(\boldsymbol{\square})$, not presalted, brine temperature at $18^{\circ} \mathrm{C}(\bullet)$.

and $\mathrm{BT}\left(12,15\right.$, and $\left.18^{\circ} \mathrm{C}\right)$ was significant $(P<0.01)$, showing that at a $\mathrm{BT}$ of $18^{\circ} \mathrm{C}$ (Table 3 , Figure 6 ), the percentage of gas holes increased much more for cheeses kept $24 \mathrm{~d}$ in $\mathrm{SB}$ at $18^{\circ} \mathrm{C}$ than in $18 \% \mathrm{~B}$ at $18^{\circ} \mathrm{C}$, and the difference increased with increasing time. There was no effect of BC for those cheeses kept $24 \mathrm{~d}$ at 12 and $15^{\circ} \mathrm{C}$. The 3 -way interaction of the linear term for time of brining $\times$ BT $\times$ presalting was significant $(P$ $<0.01$ ) (Table 3 ). The very strong impact of presalting can be seen in Figure 7, where PS cheese in combination with a $\mathrm{BT}$ of $18^{\circ} \mathrm{C}$ achieved a level of gas production that could only be achieved in nonPS cheese by reducing brine temperature from 18 to $12^{\circ} \mathrm{C}$. For all groups of cheeses (PS vs. nonPS), the percentage of gas holes increased with time (Figure 7). However, the increase with time was much greater for nonPS cheese, particularly at 15 and $18^{\circ} \mathrm{C}$. In Figure 8, pictures of 6 cheese samples are provided to illustrate the differences in gas production at $24 \mathrm{~d}$ that are shown in Figure 7 for the various treatments. The cheeses in Figure $8 \mathrm{a}$ and $8 \mathrm{~b}$ have an unacceptable level of gas production at $24 \mathrm{~d}$ of brining (Caccamo et al., 2004), whereas the cheeses shown in Figures 8c, d, e, and f would be acceptable at the end of $24 \mathrm{~d}$ of brining.

Overall, presalting at a level of $2 \%$ salt added to the curd (before stretching), combined with stretching in water containing $4.5 \%$ salt, had the biggest impact on reducing gas production in Ragusano cheese, and reducing BT had the second largest impact. Reducing BC was much less important and would only provide some benefit in reducing gas production if no presalting was done and if a BT of $18^{\circ} \mathrm{C}$ was used. However, caution should be used with lower BC because growth of unde- sirable bacteria in the brine can become a problem if the brine concentration is too low and the temperature too high.

\section{DISCUSSION}

\section{Impact of Presalting on Coliform Count}

Presalting produced a 1.41 log reduction in coliform count in the Ragusano cheese in the present study compared with similar Ragusano cheeses made without presalting. After $2 \%$ (by weight) salt was added and mixed with the curd ( $\mathrm{pH} 5.3$ ), the curd was stretched at a cheese temperature of $48^{\circ} \mathrm{C}$ in a $4.5 \%$ salt solution. The nonPS cheese had the same $\mathrm{pH}$ and was exposed to the same temperature conditions during stretching as the PS cheese. The 1.41 log reduction in coliform count due to presalting just before stretching would indicate that there was a strong 3-way interaction effect between salt and stretching temperature and curd $\mathrm{pH}$ that significantly reduced the survival of coliform in the cheese. Coliform bacteria are acid sensitive and this sensitivity is greater when combined with other factors such as increasing salt concentration or lower water activity (Choisy et al., 1987).

\section{Gas Production in Raw Milk Cheeses}

Coliform bacteria are a major contributor to early gas production in raw milk cheeses (Chapman and Sharpe, 1990). Coliform enter the cheese from the raw milk and from the environment during cheese making. After coagulation of the milk and cutting of the curd, bacteria, desirable and undesirable, are concentrated in the curd during the syneresis process. The coliform count can increase to high numbers after removal of the whey, if the temperature is favorable, and particularly if acid development is slow during cheese making (Choisy et al., 1987). In Ragusano cheese, the cheese making process relies on the natural lactic acid bacteria present in the raw milk and the lactic microflora from the surfaces of the wooden cheese making equipment typically used (Licitra et al., 1998); no starter culture is added. At times when the ambient temperature in the cheese making area on the farm is low (e.g., the winter months), acid development in the curd, produced by the low level and slow growth of natural lactic acid producing microflora, may be reduced, and the possibility for growth and gas production by coliform during brining increases. The negative impact of gas production in cheese can have 2 dimensions: 1) an undesirable and atypical appearance and texture with gas holes, and 2) undesirable or atypical aromas and flavors. In the present study, the change in appearance (i.e., increased area of the cheese surface as gas holes) was 

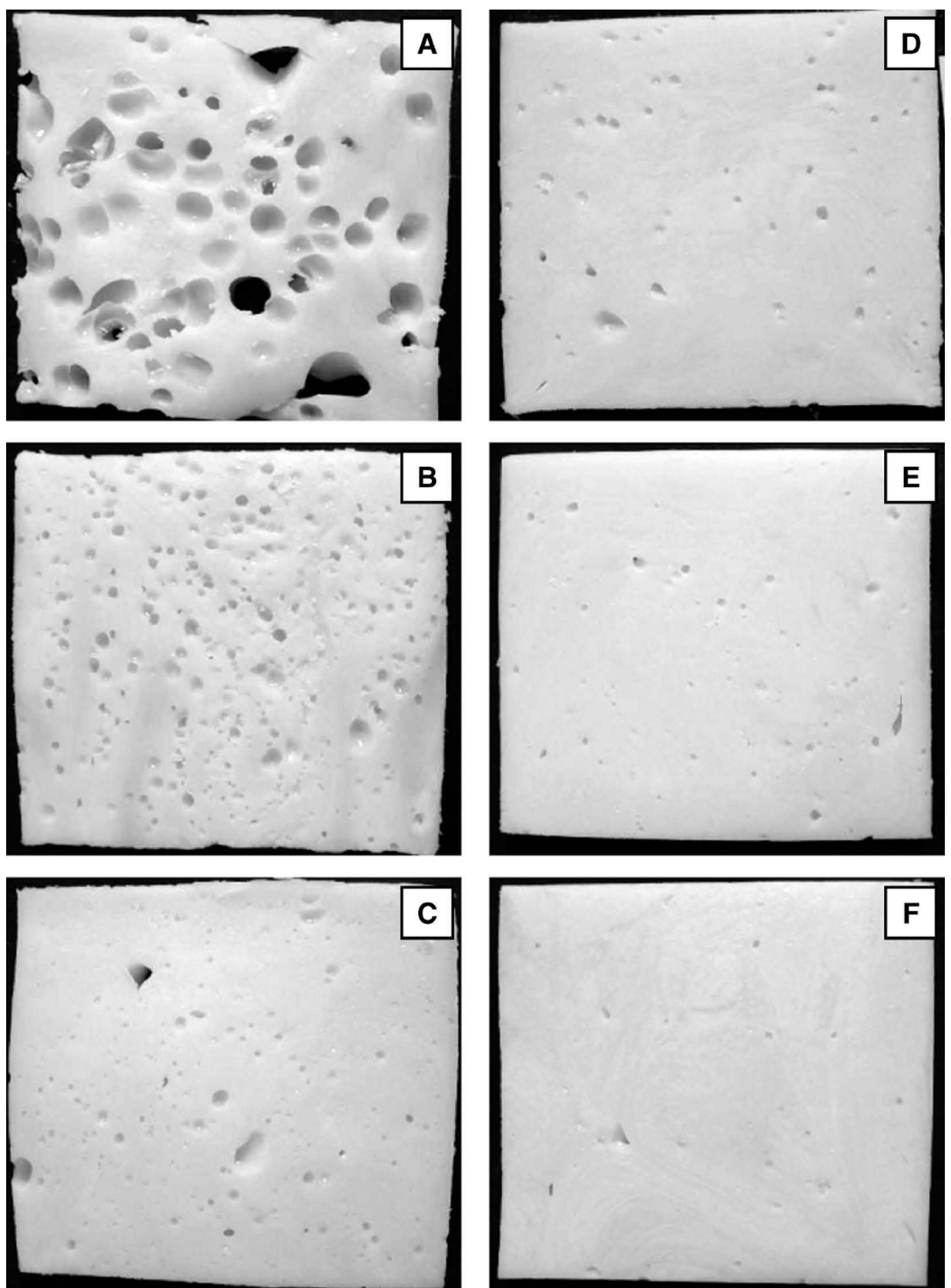

Figure 8. Image of 6 slices of cheese representing 6 different percentages of gas holes: 7\% (a), 4\% (b), 2\% (c), 1.8\% (d), 0.8\% (e), and $0.5 \%$ (f).

measured using image analysis (Caccamo et al., 2004). The number, size, shape, and distribution of gas holes within the structure of cheese was influenced by the amount of gas produced and the texture (i.e., softness) of the cheese during gas production. The same amount of gas produced in a cheese with a hard vs. a soft structure will produce a different distribution and size of gas holes. The cheese temperature will also influence 
the softness of the texture and at higher temperatures, the same quantity of gas may produce larger or more holes in the cheese structure. Production, size, and distribution of holes depend upon classical gas laws and on the solubility and behavior of the gas in the gel structure leading to saturation (Kosikowski and Mistry, 1997). Gas will continue to be produced within the cheese during aging at 16 to $18^{\circ} \mathrm{C}$. Therefore, the level of gas production at the end of brining needs to be acceptable if the cheese is going to be acceptable after 6 mo of aging.

Impact of presalting. Presalting had the largest impact of any of the variables (PS, BT, and $\mathrm{BC}$ ) on reducing gas production (as measured by image analysis) during brine salting. Certainly the significant reduction in gas production due to presalting averaged across all BT (Figure 2) had to be at least partially caused by the 1.41 log reduction in coliform count (Table 2 and Figure 1). In addition, the PS cheese contained $2.16 \%$ salt-in-moisture throughout the block at $d 0$ before brining and this would be expected to reduce gas production. The synergistic effects of salt, temperature, and low $\mathrm{pH}$ during stretching that the reduced coliform count (Table 2), may also have injured a significant portion of the remaining coliform in the cheese. This effect and the higher salt-in-moisture (2.16 vs. $0.25 \%)$ at $\mathrm{d} 0$ in the cheese had a major impact on reducing gas formation.

Impact of brine temperature. No impact of $\mathrm{BT}$ on the level of coliform in the cheese (Figure 1, Table 2) was detected and there was no change in coliform content in the cheese between $\mathrm{d} 16$ and 24 . However, BT did have an impact on the number of gas holes detected, with gas holes increasing with increasing brine temperature (Figure 3 and 7). The increase in gas holes was larger with increasing temperature in the nonPS cheese than in the PS cheese (Figure 7). It would be expected that cheeses brined at higher temperature would achieve a higher salt content (Melilli et al., 2003a) and that this might reduce gas production. However, the opposite was true. The cheeses with higher brining temperature had more of their surface area as gas holes. This could be a direct impact of the brine temperature stimulating gas production by the organisms in the cheese or it could be that the softer structure of the cheese at the warmer brine temperature, and lower solubility of gas in the cheese structure, allowed the same amount of gas to produce a larger area of gas holes. In normal practice, Ragusano cheese is brine-salted at the farm for 3 to $7 \mathrm{~d}$ before being transported to an aging center. Control of brine temperature at the farms is not very good and generally fluctuates with the ambient temperature. During the course of the current study, the ambient temperature in Sicily fluctuated from 8 to $22^{\circ} \mathrm{C}$.
Once the cheese is at the aging center, however, the temperature control of brine is much more consistent. With respect to controlling gas production, the control of temperature (i.e., avoiding high temperature) during the first few days of brining should be a priority for a farmstead cheese maker.

Impact of brine concentration. No impact of $\mathrm{BC}$ on coliform count in the cheese at 16 and $24 \mathrm{~d}$ of brining was detected (Table 2). Of the 3 main parameters studied, BC had the smallest impact on the area of the cheese occupied by gas holes, even though lower BC can have a large impact on salt uptake by the cheese. Previous work demonstrated that at $18^{\circ} \mathrm{C}, 18 \% \mathrm{~B}$ caused the salt content in the $\mathrm{P} 4$ portion of the block (where gas and coliform were measured) to reach the same level of salt concentration in $12 \mathrm{~d}$ that a block brinesalted at $18^{\circ} \mathrm{C}$ in $\mathrm{SB}$ achieved in $24 \mathrm{~d}$ (Melilli et al., 2003b). At 12 and $15^{\circ} \mathrm{C}$, there was no difference in the number of gas holes between cheeses in SB vs. $18 \% \mathrm{~B}$. However at $18^{\circ} \mathrm{C}$, the cheeses in $\mathrm{SB}$ had a much greater gas hole area at $24 \mathrm{~d}$ than the cheeses in $18 \% \mathrm{~B}$ at 24 $\mathrm{d}$. This is the only case where reduced BC decreased gas production in the cheese. This is the treatment $\left(18^{\circ} \mathrm{C}, 18 \% \mathrm{~B}\right)$ where the reduced brine concentration should have the biggest impact on increasing the rate of delivery of salt to the center of the block, based on previous research (Melilli et al., 2003b). Therefore, reduced gas production in $18 \% \mathrm{~B}$ at $18^{\circ} \mathrm{C}$ is consistent with the expected increase in salt in the center of the block that would be produced by this treatment.

\section{CONCLUSIONS}

Presalting the curd with $2 \%$ added salt before stretching, combined with stretching in water containing $4.5 \%$ salt, reduced the coliform count in the cheese by 1.41 log and had a major impact on reducing early gas formation. Averaged across all treatments in the present study, the reduction in gas formation due to presalting was $75 \%$. Reducing brine temperature had the second largest impact on reducing gas production, but had no impact on reducing the coliform count in the cheese. Reducing brine temperature from 18 to $12^{\circ} \mathrm{C}$ made larger reductions in early gas formation in nonPS cheeses (from 6.8 to $1.76 \%$ gas holes, respectively) than in PS cheeses (from 1.92 to $0.47 \%$ gas holes, respectively). To achieve the same absolute level of gas production in nonPS cheese as achieved in PS cheese at $18^{\circ} \mathrm{C}$, the brine temperature for nonPS cheese had to be lowered from 18 to $12^{\circ} \mathrm{C}$. Reducing $\mathrm{BC}$, although effective at increasing the rate of salt penetration into the block at higher BT, did not have any impact on coliform count and had minimal impact on gas production. The condition where reducing $\mathrm{BC}$ was able to make a reduction 
in gas production was for nonPS cheeses brined at $18^{\circ} \mathrm{C}$. Presalting is a very simple and practical approach to reducing the problem of early gas formation in combination with strategies to improve milk quality and cheese making conditions. Further work is needed to understand the impact of different levels of presalting on death of coliforms and gas production in the cheese.

\section{ACKNOWLEDGMENTS}

The authors thank Carlo Calvo, Paolo Nifosì, Gina Di Rosa, Sebastiano Campo, Giovanni Tumino, Rosario Tumino, Giovanni Marino, Antonio Difalco, Rosita Gambuzza, Laura Tuminello, Patrizia Campo, and Guglielmo Portelli for technical assistance. Financial support was provided by the Assessorato Agricoltura e Foreste della Regione Siciliana, Palermo, Italy.

\section{REFERENCES}

Association of Official Analytical Chemists. 2000. Official Methods of Analysis. 17th ed. AOAC International, Gaithersburg, MD.

Barbano, D. M., J. J. Yun, and P. S. Kindstedt. 1994. Mozzarella cheese making by a stirred-curd, no-brine procedure. J. Dairy Sci. 77:2687-2694.

Bester, B. H. 1976. Enkele aspekte van gasvorming deur kolivormige bacteriee in kaas. S. Afr. J Dairy Technol. 81:51-55.

Caccamo, M., C. Melilli, D. M. Barbano, G. Portelli, G. Marino, and G. Licitra. 2004. Measurement of gas holes and mechanical openness in cheese by image analysis. J. Dairy Sci. 87:739-748.

Carić, M. 1993. Ripened cheese varieties native to Balkan countries. Pages 263-280 in Cheese: Chemistry, Physics, and Microbiology. Vol. 2. Major Cheese Groups. 2nd ed. P. F. Fox, ed. Chapman and Hall, London.
Chapman, H. R., and M. E. Sharpe. 1990. Microbiology of cheese. Pages 203-289 in Dairy Microbiology. Vol. 2. R. K. Robinson, ed. Elsevier, London.

Choisy, C., M. Gueguen, J. Lenoir, J. L. Schmidt, and C. Tourneur. 1987. The ripening of cheese: Microbiological aspects. Pages 250 292 in Cheesemaking-Science and Technology. A. Eck, ed. Lavoisier Publ. Inc., New York, NY.

Geurts, T. J., P. Walstra, and H. Mulder. 1972. Brine composition and the prevention of the defect "soft rind" in cheese. Neth. Milk Dairy J. 26:168-179.

Geurts, T. J., P. Walstra, and H. Mulder. 1974. Transport of salt and water during salting of cheese. 1 . Analysis of the processes involved. Neth. Milk Dairy J. 28:102-129.

Glantz, S. A., and B. K. Slinker. 2001. Multicolinearity and what to do about it. Pages 185-187 in Primer of Applied Regression and Analysis of Variance. 2nd ed. McGraw-Hill, Inc. New York, NY.

Kosikowski, F. V., and V. V. Mistry. 1997. Page 228 in Cheese and Fermented Milk Foods. Vol. 1. Origins and Principles. F. V. Kosikowski, LLC, Westport, CT.

Licitra, G., G. Portelli, P. Campo, G. Farina, S. Carpino, and D. M. Barbano. 1998. Technology to produce Ragusano cheese: A survey. J. Dairy Sci. 81:3343-3349.

Marshall, R. T. 1992. Standard Methods for the Examination of Dairy Products. 16th ed. Am. Publ. Health Assoc., Washington, DC.

Melilli, C., D. M. Barbano, G. Licitra, G. Portelli, G. Di Rosa, and S. Carpino. 2003a. Influence of temperature of salt brine on salt uptake by Ragusano cheese. J. Dairy Sci. 86:2799-2812.

Melilli, C., D. M. Barbano, G. Licitra, G. Tumino, G. Farina, and S. Carpino. 2003b. Influence of presalting and brine concentration on salt uptake by Ragusano cheese. J. Dairy Sci. 86:1083-1100.

Mulvaney, S. J., S. Rong, D. M. Barbano, and J. J. Yun. 1997. Systems analysis of the stretching of Mozzarella cheese. J. Dairy Sci. 80:3030-3039.

Resmini, P., G. Volonterio, S. Annibaldi, and G. Ferri. 1974. Studio sulla diffusione del sale nel formaggio Parmigiano-Reggiano mediante l'uso di $\mathrm{Na}^{36} \mathrm{Cl}$. Sci. Tec. Latt. Cas. 25:149-166.

Turhan, M., and G. Kaletunç. 1992. Modelling of salting diffusion in white cheese during long term brining. J. Food Sci. 57:1082-1085.

Zorrilla, S. E., and A. C. Rubiolo.1991. Average $\mathrm{NaCl}$ concentration in cheese for different volume ratios of brine and solid during salting. J. Food Sci. 56:1548-1551. 